Tomasz Ludwicki (iD https://orcid.org/0000-0002-6792-6727

Wydział Zarządzania

Uniwersytet Warszawski

e-mail: t.ludwicki@uw.edu.pl

Monika Kostera (D) htps://orcid.org/0000-0002-5303-5544

Institute of Culture, the Jagiellonian University

School of Social Sciences at Södertörn University, Sweden

e-mail: monika.kostera@sh.se

\title{
LEARNING TO COOPERATE: IMPLICATIONS FOR HUMANISTIC MANAGEMENT
}

\begin{abstract}
The contemporary business education has been promoting competition to the detriment of cooperation. This is unfortunate, given the magnitude and complexity of the current crisis facing humanity: a situation which urgently requires cooperation. Based on an ethnographic study of IT management consultants, we propose a practice-based framework for education and training rooted in humanistic management principles to remedy this lack.
\end{abstract}

Keywords: cooperation, collaboration, ethnography, education, business school

\section{Introduction}

\section{The Polish Landscape}

During an ongoing ethnographic study of alternative organizations active in Poland and the UK, a cooperative organizer expressed the following criticism of the state of knowledge available for Polish alternative organizers and managers:

The more people work together, the more they see that they can do much more. (...) We are not taught this at school, at the university; all the time it is only about entrepreneurship, competition, but there's no cooperation. And then they say people don't cooperate and that competition is natural. We have to learn everything ourselves. (Mateusz) ${ }^{1}$

1 All real names have been replaced by pseudonyms for the sake of anonymity in this paper. 
In Poland, as in the entire modern world, there has been an explosion in numbers and influence on education of business schools in the decades from the 1990s and onward. ${ }^{2}$ This global trend has been recently pertinently depicted by Martin Parker ${ }^{3}$ in his much cited book, Shut Down the Business School, in which he presents the contemporary business school as an institution spinning strongly ideological tales promising unmitigated growth, and a mindset based on calculation, individualism, competition and greed on a mass global scale. The famous 5 forces model of Michael Porter dating from 1979 not only omits any possible cooperation between the parties involved but also adopts a language of conflict and war: retaliation, barriers and powers. ${ }^{4}$ Furthermore, a reedit of the article from 2008 does not bring any change in this regard: the word "cooperation" is not used even once.

At the same time, as humanity, we need a different mindset more urgently than ever to combat the dissolution of culture and society, and to remedy the destruction of the planet. We must replace the business school with something responsible, such as schools of organizing focusing on different and important aspects of business and organizations, such as respect for the ecosystem, social inclusion, cooperation, justice, appeals Martin Parker. We focus, in this text, on the Polish case, as our empirical material derives from Poland, but the implications are, we argue, similar for managers and organizers globally.

In Poland, as in the West, there is a huge number of higher education institutions teaching management and entrepreneurship along the lines sketched by Martin Parker. Similar courses are offered to students of a variety of non-business related subjects, from drama schools to medics. Entrepreneurship, understood as the promotion of individualistic mindset striving for success on a competitive market, ${ }^{5}$ appears in the core curricula of Polish high schools and technical schools, and is also taught to students of vocational schools. ${ }^{6}$ Some primary schools offer lessons in entrepreneurship and the objectives of education in grades from 4 to graduation include developing competences in thus defined entrepreneurship. ${ }^{7}$ There are even kindergartens teaching

See e.g. M.J. Hatch, M. Kostera, A.K. Koźmiński, Three Faces of Leadership: Manager, Artist, Priest, Blackwell, London 2005.

3 M. Parker, Shut Down the Business School, Pluto, London 2018.

4 M. Porter, The Five Competitive Forces That Shape Strategy, "Harvard Business Review” 1979/2008, January, pp. 79-93.

5 For a discussion of the terms management and entrepreneurship in the Polish context see for example M. Huczek, Zarządzanie jako czynnik rozwoju przedsiębiorczości, "Przedsiębiorczość - Edukacja" 2009, no. 5, pp. 88-98.

6 Podstawy przedsiębiorczości. Podstawy programowe. Liceum/technikum, 2018, https://podstawaprogramowa.pl/Liceum-technikum/Podstawy-przedsiebiorczosci (accessed: 3.12.2020); M. Gaertner, Podstawy przedsiębiorczości. Program nauczania dla szkót ponadpodstawowych (liceum i technikum), OPERON, Gdynia 2019.

7 Podstawy programowe. Szkoła podstawowa IV-VIII, 2017, https://podstawaprogramowa.pl/Szkola-podstawowa-IV-VIII (accessed: 3.12.2020). 
entrepreneurship. ${ }^{8}$ Children and adolescents learn to make financial decisions, design activities of the enterprise, acquire "basic skills of competitive behaviour." Among the objectives of entrepreneurship classes for high schools and vocational schools is "Appreciating the role of entrepreneurs responsible for building a competitive economy and recognizing the importance of economic freedom and private property as pillars of the market economy." 10 A vocational school student, among other things, "recognizes the strengths and weaknesses of his own personality; relates them to the characteristics of an enterprising person; (...) knows the benefits of planning your own activities and investing in oneself"11 and "prepares a project of his own enterprise based on a business plan."12 There are numerous extracurricular activities ${ }^{13}$ and competitions ${ }^{14}$ and educational platforms ${ }^{15}$ promoted and funded by a variety of institutions, including charities, businesses, the Polish National Bank and public institutions, including the Polish Ministry of Education. The necessity to acquire such knowledge is justified as follows:

[Students] should therefore have basic knowledge not only in the field of exact sciences, natural sciences and humanities, but also social sciences, especially economics. This knowledge provides the basis for shaping the skills and entrepreneurial attitudes needed to function in the modern, globally conditioned economy. ${ }^{16}$

On the other hand, there is less evidence, in the Polish educational system, to recognize the necessity to shape the attitudes of cooperation and cooperation, no programmes, no courses, no higher education institutions dedicated to this aim and, indeed no, specific educational goals. Just as our interviewee quoted at the beginning said, organizers and managers have to learn everything themselves.

8 T. Rachwał, W. Kilar, Z. Kawecki, P. Wróbel, Edukacja w zakresie przedsiębiorczości w wychowaniu przedszkolnym, szkole podstawowej i szkołach średnich $w$ świetle nowej podstawy programowej, "Przedsiębiorczość - Edukacja" 2018, no. 14, pp. 299-424, DOI: 10.24917/20833296.14.28.

$9 \quad$ Podstawy programowe. Szkota podstawowa IV-VIII, op. cit.

10 Podstawy przedsiębiorczości. Podstawy programowe. Liceum/technikum, 2017, https://podstawaprogramowa.pl/Liceum-technikum/Podstawy-przedsiebiorczosci (accessed: 3.12.2020).

11 Podstawy przedsiębiorczości. Cele kształcenia - wymagania ogólne. Branżowa szkoła I stopnia, 2017, https://podstawaprogramowa.pl/Branzowa-szkola-I-stopnia/Podstawy-przedsiebiorczosci (accessed: 3.12.2020).

12 Ibidem.

13 See e.g. Instytut Wolności, Przedsiębiorczy w życiu $i$ w szkole, 2017, http://przedsiebiorczosc.instytutwolnosci.pl/ (accessed: 3.12.2020) [addressed to students at all levels of education]; Szkoła Podstawowa nr 369, Przedsiębiorczość, 2020, https://sp369.edupage.org/text2/ (accessed: 3.12.2020).

14 Olimpiada Przedsiębiorczości, Biznes w uwarunkowaniach zrównoważonego rozwoju, 2020, http:// www.olimpiada.edu.pl/ (accessed: 3.12.2020).

15 Centrum Edukacji Obywatelskiej, Młodzi przedsiębiorcy, 2020, https://przedsiebiorczy.ceo.org.pl/o-programie-od-a-do-z (accessed: 3.12.2020).

16 Podstawy przedsiębiorczości. Podstawy programowe. Liceum/technikum, 2017, op. cit. 


\section{The Broader Picture}

At the same time, the current state of the world urgently demands a radical change of collective action. This urgency stems from a state of fundamental systemic crisis, known as the interregnum, the state between working social systems, as diagnosed by sociologists, ${ }^{17}$ as well as economists, ${ }^{18}$ including the disastrous state of the ecosystem ${ }^{19}$ and unprecedented financial collapse. ${ }^{20}$ This bleak state of the world has been exacerbated further by the global pandemic of COVID-19, making it an imperative for humanity to take action now, less our civilization is extinct. ${ }^{21}$ Work has become divorced from meaningfulness, ${ }^{22}$ social good and usefulness. ${ }^{23}$ Management is disconnected from responsibility and managers have become celebrities, regardless of their lack of effectiveness, accountability, social skill or even basic compassion. ${ }^{24} \mathrm{We}$ have forfeited the ability to lead and experience the good life due to the insatiability provoked by the morbid lifestyle haunted by the relentless competition for more and more, usually defined in monetary terms. ${ }^{25}$ Edward Skidelsky and Robert Skidelsky warn that such a mindset makes life not worth living. There are several values and competencies which, according to them, would help us to retrieve the sense of the good life - among them friendship and cooperation. Likewise, the economist Guy Standing strongly suggests that contemporary societies should reclaim the notion of the common good and re-learn cooperation in order to manage and sustain it. ${ }^{26}$ Bruno Latour $^{27}$ urges humanity to dedicate our politics to develop an interaction not just with each other but with other beings and natural phenomena. In the Antropocene, he argues, our actions have vital implications for far more than just human societies. He proposes a political system of engendering, acknowledging and putting at its heart a wide and close net of interactions and cooperative efforts; a 'terrestrial' way of doing politics. The current striking imbalance of management and managerial education, combined with their almost omnipresence and global dominance, ${ }^{28}$ make

17 Z. Bauman, Times of Interregnum, "Ethics and Global Politics" 2012, no. 5/1, pp. 49-56.

18 W. Streeck, How Will Capitalism End? Essays on a Failing System, Verso, London 2017.

19 N. Klein, No Is Not Enough: Defeating the New Shock Politics, Penguin, London 2017; B. Latour, Oú atterir? Comment s'orienter en politique, Éditions de la Découverte, Paris 2017.

20 A. Tooze, Crashed: How Decade of Financial Crises Changed the World, Allen Lane, London 2018.

21 E. Morin, Changeons de voie. Les leçons du coronavirus, Denoël, Paris 2020.

22 P. Fleming, Resiting Work: The Corporatization of Life and Its Discontents, Temple University Press, Philadelphia 2014.

23 D. Graeber, Bullshit Jobs: A Theory, Allen Lane, London 2018.

24 P. Bloom, C. Rhodes, CEO Society: The Corporate Takeover of Everyday Life, Zed Books, London 2018.

25 E. Skidelsky, R. Skidelsky, How Much Is Enough? Money and the Good Life, Penguin, London 2012.

26 G. Standing, Plunder of the Commons: A Manifesto for Sharing Public Wealth, Pelican, London 2019.

27 B. Latour, Oú atterir ..., op. cit.

28 M. Parker, Shut Down..., op. cit. Polish edition: Rozwalić szkoły biznesu. Co trzeba zmienić w nauczaniu zarządzania?, Wydawnictwo Naukowe PWN, Warszawa 2019. 
the challenges outlined here something of a mission impossible. We need to learn cooperation and collaboration and we need to start now.

This paper addresses the urgent issue of learning cooperation in a traditional corporate setting. Based on an ethnographic study of a consulting, we outline some practical issues and solutions to the need for learning to collaborate. We link the findings to the programme for the renewal and reform of management philosophy as upheld by the humanistic management turn. Finally, we propose concrete policy solutions deriving from the study and its interpretation in terms of humanistic management.

The contribution to knowledge of this text concerns the possible development of a management education aimed at inculcation and promotion of collaboration and cooperation, in the spirit of the Humanistic Management Network's goals and ideals supporting human dignity, as well as based on the humanistic vision of the human condition with the broad ecosystem, as more inspired by cooperation than competition.

\section{Humanistic management: A path towards collaborative perspectives}

The humanistic turn in management is a fairly recent phenomenon, but it abounds already in a rich and extensive literature. ${ }^{29}$ It focuses on a consciously humanistic management creed, and promotes humanistic values and a respect for the human condition. $^{30}$

Humanistic management is both a theoretical reflection and a practice which can be defined by three key characteristics: as a value based approach to management, as a managerial competence derived from humanities, and as an experience-based perspective on managing and organizing. ${ }^{31}$ In its value based guise, it focuses mainly of human well-being, emancipation and development. It is concerned about the development of a managerial philosophy which is dedicated to the safeguarding and care of the human condition, needs and rights. Managers should, according to this creed, learn how to take responsibility for the common good, dignity, emancipation and development of the human being. ${ }^{32}$ Its foundation is based on Kantian ethics, sustaining that the human beings should never be regarded as a means to any end, such as profit,

29 For an overview see e.g. M. Kostera, Humanistic Management [in:] B. Czarniawska (ed.), A Research Agenda for Management and Organization Studies, Edward Elgar, Cheltenham 2016, pp. 38-48; M. Pirson, H. Spitzeck, W. Amann, Sh. Khan, E. von Kimakowitz (eds.), Humanism in Business, Cambridge University Press, Cambridge 2009.

30 See e.g. M. Pirson, U. Steinvorth, C. Largacha-Martinez, C. Dierksmeier (eds.), From Capitalistic to Humanistic Business, Palgrave Macmillan, London 2014.

31 See e.g. J. Kociatkiewicz, M. Kostera, Zarządzanie humanistyczne. Zarys programu, "Przegląd Zarządzania” 2013, no. 4, ed. B. Nierenberg, Special Issue, pp. 9-19.

32 Humanistic Management Network, Our Foundations, 2018, http://humanisticmanagement.network/ about-us/ (accessed: 3.12.2020); for elaboration, see also: H. Mintzberg, Rebalancing Society: Radical Renewal Beyond Left, Right, and Center, Berrett-Koehler, Oakland 2015. 
economic growth, or efficiency, but should only be seen as an end in themselves. ${ }^{33}$ All other moral principles and obligations of the manager result from the obligation towards the human beings in his or her responsibility. As a perspective defined by competence, it seeks profound inspiration and guidance in the humanities, rather than in economics, and it concerned both about knowledge and a kind of cultural sensitivity. ${ }^{34}$ It not only concerns the technical aspects of how to manage, but also the knowledge of the context and its various aspects: political, historical, ethical and ecosystemic. Such knowledge inspires collaborative, rather than competitive, learning modes that can contribute to creative attitudes and activities. Finally, as a perspective interested in the human condition and experience, it seeks to understand in a compassionate and enlightened way organizational realities from the point human point if of view. ${ }^{35}$ Through the understanding of human attitudes and motivations, and by considering the human being as part of a broader ecosystem, it enables a longer and broader view than a reductionist approach aimed at satisfying shareholders by offering them financial value. ${ }^{36}$

In all these guises humanistic management is strongly dedicated to the promotion of collaboration, co-responsibility and cooperation, not just as an important competence and ability, but as a managerial philosophy. It is rooted in the conviction that such an approach is linked to the most fundamental value for management to uphold, namely, dignity. The Humanistic Management Manifest published by the Humanistic Management Network states the following:

In business as well as in society, respect for human dignity demands respect for human freedom. Collective decision-making, in corporations just as in governments, should hence be based on free and equal deliberation, participation or representation of all affected parties. Concerns of legitimacy must, in economics like in politics, precede questions of expediency.

The Humanistic Management Network defends human dignity in face of its vulnerability. The dignity of the human being lies in its capacity to define autonomously the purpose of its existence. Since human autonomy realizes itself through social cooperation, economic relations and business activities can either foster or obstruct human life and well-being. Against the widespread objectification of human subjects into human resources, against the common instrumentalization of human beings into human capital and a mere means of production, we uphold humanity as the ultimate end and principle of all economic activity. ${ }^{37}$

33 I. Kant, Groundwork of the Metaphysics of Moral, Cambridge University Press, Cambridge 1997.

34 P. Gagliardi, B. Czarniawska (eds.), Management and Humanities, Edward Elgar, London 2006; E. Orzechowski, Dziś nawet żebrak musi być sprawnym menedżerem. O zarządzaniu kulturą i szkolnictwem wyższym, Attyka, Kraków 2009.

35 See e.g. B. Czarniawska-Joerges, P. Guillet de Monthoux, Good Novels, Better Management: Reading Organizational Realities, Harwood, Chur 1994.

36 See e.g. H. Mintzberg, Bedtime Stories for Managers, Berrett-Koehler, Oakland 2019; M. Kostera, After the Apocalypse? Finding Hope in Organizing, John Hunt Publishing / Zero Books, Washington 2020.

37 Humanistic Management Network, The Humanistic Management Manifest, 2018, http://humanisticmanagement.network/about-us/ (accessed: 3.12.2020). 
These are important and potentially radical ideas that may transform the business school in directions sought for by the authors and practitioners cited in the introduction to this paper. But how can they be best applied in the practice of managerial education? In the humanistic management tradition, we will seek guidance in actual experience and based on it, propose some concrete policy recommendations. Collaborative activities are at heart of the HMN values, forming the foundation for the search for new form of organizations and new ways in which existing ones may change their workplace practices and human relations. We shall first narrate some findings from an ethnographic study carried out in a consulting firm concerning how managers and consultants learn collaboration and then relate the material to the humanistic management programme goals.

\section{Ethnographic Study of Management Consultancy IT}

\section{Methodology}

Management consultants in the IT sector ${ }^{38}$ have attracted much interest in comparison with other types of consulting. Apart from the much cited study of Enator ${ }^{39}$ by Mats Alvesson ${ }^{40}$ there are many other notable texts addressing various aspects of work of in the IT management business, from power, via professional skills, to social roles. ${ }^{41}$ Alvesson's work is mainly concentrated on the organizational level and little is known about the relationship between consultants and clients. Brian Bloomfield, Ardha Best, Theo Vurdubakis, and Ardha Danieli, on the other hand, present detailed descriptions of consulting projects but the consulting companies and their employees are more in the background. Andrew Sturdy studied consultants and their work but his interpretation of the client-consultant relationship is presented on the organizational field level: between clients and consultancies in general, and not as a particular

38 I differentiate IT consultants and management consultants in IT. The first group may consist of programmers, hardware consultants and so on. The second consist mainly of consultants responsible for parameterization of system like financial-accounting system, ERP system and so on. This division is based on my research: management consultants wants to be perceived different from programmers. Currently Tieto-Evry.

40 M. Alvesson, Management of Knowledge Intensive Companies, Walter de Gruyter, Berlin-New York 1995.

41 E.g.: B. Bloomfield, A. Best, Management Consultants: System Development, Power and the Translation of Problems, "The Sociological Review" 1992, no. 92, pp. 533-560; B. Bloomfield, T. Vurdubakis, The Outer Limits: Monsters, Actor Networks and the Writing of Displacement, "Organization" 1999, vol. 6(4), pp. 625-647; B. Bloomfield, A. Danieli, The Role of Management Consultants in the Development of Information Technology: The Indissoluble Nature of Socio-political and Technical Skills, "Journal of Management Studies" 1995, vol. 32, no. 1, January, pp. 23-47; A. Sturdy, The Consultancy Process - An Insecure Business?, "Journal of Management Studies” 1997, vol. 34, no. 3 , May, pp. 389-413. 
client-consultancy relationship. All the studies throw informative light on the profession, but the issue of collaboration is usually in the background.

The primary study upon which this paper is based was carried out ${ }^{42}$ is an ethnography of a leading management consulting IT firm in Poland ${ }^{43}$ called Cons-IT. The whole research project lasted for 19 months and the intensity varied, according to the work cycles of the consultants. Ethnography is a research perspective with roots in the humanities and social sciences and enables an empathic and rigorous study based on prolonged and intensive immersion in the field. ${ }^{44}$ It seeks local knowledge and is concerned about patterns and processes, rather than a statistical representation of a broader population. It enables an understanding of practices and cultural processes in context. ${ }^{45}$

The following methods were used: open and semi-structured interviews, observations and document analysis. The researcher was not granted access to the consultants' internal meetings, however, he had the chance to study the development of a single project from its beginning to implementation. Most of the interviews were tape-recorded and transcribed. ${ }^{46}$ Then texts were classified into categories and quotations were grouped in each category. Finally, the categories were analysed and structure emerged from the material. ${ }^{47}$ The client-consultant relationship was only one of the topics of the study. This study is dated from two decades ago, however, its relevance came recently into light in connection to the second study, by the other co-author, which we refer to in this text only in a cursory manner. The citation introducing this paper comes from this second research project. It is also an ethnographic research endeavour, still ongoing. Similar research methods are being used. The theme of cooperation is one of its leading categories. We realized that this theme is reflected in a most pertinent way by the first study. That is the reason why we decided to write this paper and why the results from the older study are its main empirical focus. However, the more recent study serves both as thematic triangulation and as reflexive empirical material, serving to make the results more valid. ${ }^{48}$

42 Part of a larger project conducted by one of us under the supervision of the other co-author.

43 Name of the company can is disguised for privacy reasons. This is one of the biggest ten IT management consultancies in Poland. It employs more than 100 consultants and offers wide range of products and services.

44 J. Van Maanen, Tales of the Field: On Writing Ethnography, University of Chicago Press, Chicago 1988; T.J. Watson, In Search of Management: Culture, Chaos and Control in Managerial Work, Thomson Business Press, London 1994; M. Kostera, Organizational Ethnography: Methods and Inspirations, Studentlitteratur, Lund 2007.

45 For a recent application of ethnography in managerial education in Poland see: S. Banaszak, Menedżerowie w społeczeństwie wspótczesnym, Wydawnictwo Naukowe UAM, Poznań 2019.

46 Only two interviews were informal.

${ }^{47}$ This process was more structured. It took many readings and re-categorize to arrive at final structure.

48 A.L. Cunliffe, Reflexive Inquiry in Organizational Research: Questions and Possibilities, "Human Relations" 2003, no. 56/8, pp. 983-1003. 


\section{Cooperation with the Client}

An IT project begins with the definition of the goal. This process requires the translation of the client's categories to the consulting firm's language. The involved participants need to clarify things. In the words of one of the interviewees, it is a bit like defining collaboratively what is "a good tea". Establishing a common language takes time and is not always successful. To take an example from the research material, the "automation of a process" may be understood differently by consultants and by the client. For the client it means that every step of the process will be supported by the IT system. For the consulting firm it is "only" $90 \%$ of the activities since the final $10 \%$ would cost additional $90 \%$ of the budget. In other words, what is supposed to give control over the identity is not always understood in the same manner by both parties.

(...) in the case of business intelligence solutions we are too often sinking in the magma of data. You don't know what is supposed to be a desired result of the project. Yeah, we finally agree that we need some reports because the human mind desperately desires some rationality behind the project. The project itself is loaded with ambiguity and uncertainty, and the final goal is that it is supposed to be better. Those reports and 'hard results' are in a way a side effect of the implementation. (Project leader)

Also picturing clients as social actors seeking to control the environment or identity of the organization is a simplification of mundane internal politics of organizations, yet this is quite a common thread to be found in consultant-client communications. This has many significant consequences for the development of their cooperation. A project may be designed to address needs of specific managers or even individuals who want to strengthen their position. On the other hand, if the consultants fail to understand a client's goals they may fail to meet the expectations. For example:

Once we lost the deal when the head of IT department was the project leader on the client's side. He asked us: "Do you want to give 200 middle line manages access to the real income and cost data? And allow our shareholders find the truth? No way!!!” And we were kicked off from this project. (Piotr)

To take an example from the study, a failure to address the communicative gap a failure to cooperate on discrepant visions - may end in a failure of the whole project. Following one of the management fashions, namely Business Intelligence, the consultants offered a solution that would be available to all middle line managers to access real financial results in different cross-sections of the organization. However, the client realized that it would decrease the position of IT manager in the social hierarchy of the organization. So, despite the fact that it would fit well to address the issue of security, it was finally not accepted by the client organization. 


\section{Consulting Work as Cooperation}

From the perspective of the consultants, a project is a never ending struggle with the client, budget, deadlines and IT systems. Since the goals of the project are not clear, the consultants have to take a step by step approach and try to gradually clarify them. In order to structure the process they need to put a structure to their emerging cooperation. For this purpose they use what they label "methodologies" as well as project documentation. However, these elements can be regarded as more of a rhetorical strategy than what the labels suggest (and how the client often sees them), i.e. as a standardized set of solutions. The firm consciously advertises it that way to the clients. In that guise it is described as

a global solution. It has been certified and was repeated in many countries where the system was implemented. So you know how to proceed. You just know what to do. It is a standard. (Piotr)

However, the consultants themselves claim that there is no such thing as a methodology that would meet such criteria. "Methodology" is just a "description of what is obvious and taken for granted" (project leader). Or it is just "any course of action taken by consultants in order to finalize the project" as one of my informants noted (project leader). It can be said to be a materialization of the imperative to cooperate embedded in the work itself. It facilitates cooperation at every step of the process and it is intentionally left obscure towards the outsiders, such as the clients, prohibiting them from disrupting the most vital collaborative elements of the work being carried out. The slightly pompous labels ("methodology", documentation) mean to impress and detract - and discourage from interference into some matters, while leaving other areas open for cooperation.

\section{Cooperation between Consultants}

Proqnos has evolved over the years from a small consulting boutique to a big company employing more than 100 consultants (not counting other personnel categories). The organization is divided into different departments specialized in the sales and implementation of IT systems for companies. As the company grew, many forms of division of tasks, such as procedures and job descriptions, were introduced. Of course, budgeting was one of the key internal procedures. Some consultants hope that it might deliver solid results:

It will be easier for us in the department when we formalize it clearly. Procedures might be great but of the document is not well written and sealed with a stamp, there would be always somebody to question them. It might lead to a loss of time and unnecessary discussions and possible conflicts instead of constructive work. (Pawel) 
This view is shared among some of the managers and project leaders. Not everybody is happy with this: there are some critical views on the formalization and its influence on the company:

I can't hide it: it is very important in every company if you like or not. You might prefer to work with one person not the other. The exchange of information, this kind of understanding is greater and sometimes it is not. This is something one can't undervalue. (Maria)

The growth of the company was reinforced at a certain moment by structurization dynamics which involved ownership issues that caused a hidden centralization. The latter is usually not addressed openly, especially on formal occasions, but is a very strong and real undercurrent of everything that, from that moment and on, was going in in the organization. Some of the changes went far beyond the formal descriptions and imposed financial goals. Even though the rules seemed to be clear they brought uncertainty and loss of the control by the employees. This made collaboration more, not less difficult. This is how it was described by one of the directors of the departments in Cons-IT:

(...) budgeting implemented itself in some invisible way (...). We are all aware, that our spending, our costs, have to comply with some rules, some boarders. However, we do not control those borders, nor do we control the rules, since they are controlled by somebody higher [in the structure]. (Piotr)

The process of introducing formal elements of management was introduced topdown by the Management Board. This is commented upon by the consultants, but mainly informally. They perceive it as an obstacle to collaboration - because collaboration needs to be carried our horizontally. Procedures developed by the consultants themselves help to work together, but procedures imposed form above make it more difficult.

The main stronghold of the potential to develop ongoing collaboration is, and has always been, the internal culture. The organization emerged as a group of colleagues, peers with extensive personal, informal relations. This network was then transformed into a corporation. It still holds a potential to negotiate, work together, exchange ideas, but the subsequent formalization led to some negative relations towards the system and its top-down influence over the internal cooperation in the firm:

Departments now are much more separated, the borders are sharper. There are procedures for allocation of the internal costs of the projects. (...) It was disgusting for us! (Darek)

Flexible cooperation, freedom in participation in projects as well as sharing knowledge, offering to help to a team in trouble is seen as highly helpful. However, the more formalized the firm becomes, the more often the culture collides with imposed procedures and budgets.

Learning the job is a collaborative process, made effective by the old culture of exchange and support. One of the senior managers describes the process of becoming a fully professional employee as "on-the-job-training" in which: 
(...) the source of your knowledge is your first project. Of course it depends on leaders and how much knowledge they would like to convey and show: actually we learn from each other. Kudos to the others who showed and taught us. We also ask others with experience in this industry. (Anna)

However, the division of tasks and centralization create some doubts, uncertainty and even ambiguity not only about the role of the consultants but also future of the company. One of the senior consultants shared a very dark vision of the future of the company, increasingly fragmented and thus less and less able to learn:

Just to make it clear... it is not that we just complain and do not work. I just want to say, what is the direction of the changes. This will lead to silos, vertical separation. In 3 years we wouldn't know each other. We would have 4 separate offices each with 30-50 employees. Just that! (Paweł)

A study from the 1990s presents management consultants as the missionaries of the capitalism, bringing into practice new capitalistic methods. ${ }^{49}$ Proqnos is a good example of such "missionary firms", bringing in new managerial fashions and techniques, such as budgeting and KPIs. Moreover, similar tools are implemented by the way of the IT services they provided to their clients. At the same time, consultants occupying various positions, as well as managers, are aware of the limitations and negative consequences of such methods. They learn from what they themselves propagate and implement. However, with the increasing formalization, making active use of their knowledge is made increasingly more difficult. Cooperation is being replaced by competition for scarce resources due to the structurization dynamic. This leads to limited sharing of knowledge and experiences. The key factor benefitting the development of the company as well as the collective feeling that the firm was a common good, is being increasingly devalued and even lost. This alienation of the consultants from their work environment leads to anxiety and uncertainty for the company's future. In order to deal with it, additional managerial methods are introduced, such as mission statement and CSR. However, this more resembles fighting fires with fuel than real help, according to the informants: it adds a layer of hypocrisy to the internal communication and it serves to conceal the actual dynamic of centralization that is taking place. People are dissatisfied with it and express their strong preference for collaborative processes. This is a striking contradiction of the common myth that managers are inclined to compete and do not value cooperation. In the researched organization the consultants and managers value collaboration and cooperation above anything else in the firm. They also value the cooperation with customers during the implementation of the projects, even though they like to impose some limits on it, which would help them to use their professional judgment. Since the centralization, they see that cooperation is made increasingly difficult. They regard it as

49 M. Kostera, The Modern Crusade: The Missionaries of Management Come to Eastern Europe, "Management Learning" 1995, no. 26/3, pp. 331-352. 
a destructive factor. Furthermore, due to structural changes they are not able to work together to remedy this. It is not consultants or managers who forfeit collaboration. It is the centralizing dynamics that pressurizes them to abandon practices that they themselves hold very dear.

\section{Discussion: How to teach collaboration}

Our empirical material shows that not only cooperative and alternative organizers recognize cooperation and collaboration as an inherent value as well as a necessary element of their work. Managers and consultants in a fairly mainstream setting also do that. Moreover, they have ways of developing and learning cooperation as an on-the-job training process. However, changes introduced top-down make that difficult and maybe even impossible in many instances, that rely on emergent process of negotiation meaning, language and practices. The first condition that needs to be observed, if we are to reclaim the value of cooperation, is the urgent removal of structural obstacles which make it difficult or impossible. Following Henry Mintzberg's ${ }^{50}$ accurate observations, the first and foremost change that needs to be introduced is to a major restructurization, the abolishment of ownership forms that cause the divorce between management and responsibility, such as, most blatantly, the shareholder value model. It is imperative to reintroduce forms such as the family firm, cooperative or other forms which invite more responsibility and less drive for maximization of financial indexes. The latter fosters competition and antagonism, and not because this is "human nature" to be competitive or because "managers are competitive" but for structural reasons. Alter the structure and other dynamics will emerge. Just as our research material form the IT consulting firm shows, albeit in the opposite direction. The study of alternative organizations that we use as reflexive material, supports and emphasizes this statement. As Mintzberg's publications demonstrate you do not have to be a Marxist (even though that is not ruled out) in order to call for changes in ownership structure nowadays.

When such necessary changes are introduced, people will be able to learn cooperation from each other. In order to support these learning processes, we propose some additional more formal training, in the spirit of humanistic management. Our empirical material suggests that the following areas would be of key importance in such training programmes.

Firstly, language is an important element of all cooperative and collaborative processes. People need to extend their language skills and to make their language more nuanced. This would facilitate day-to-day negotiations over meanings related to tasks that are to be carried out in common, but also help in situations where a common identity is needed or important limits are to be set against the environment (such as the client). An education in the humanities would be very useful for these purposes.

50 H. Mintzberg, Bedtime Stories..., op. cit. 
Secondly, knowledge of and about the human condition is vital, and not just about decision making skills but also other important aspects of what it means to be human. This would enable to train and develop our moral abilities and to support the respect for human dignity, even in our very complex social world of today where diversity is an inherent and important factor. To understand the Other and to develop empathy is just as important as to be able to make common decisions. The training in all areas related to the human condition would be necessary in the model of education which we propose.

Thirdly, the value of an experience based perspective postulated by humanistic management is supported by our empirical material. The consultants are able to learn cooperation by and from experience and no formal procedures or schooling can replace that mode of learning. That does not mean that procedures cannot be helpful; quite the opposite. If applied well, they are a form of performative language ${ }^{51}$ with particularly practical day-to-day consequences. However, they should not be presented as a replacement of embodied, experiential knowledge. That makes the traditional case study perpetually relevant, however, we would argue for the inclusion of more cases based on ethnographic research, because they are particularly close to the level of human experience.

All in all, our research makes a strong argument for the education of managers and organizers in accordance with the leading ideas of humanistic management, if cooperation and collaboration is to be developed and supported - if the basic structural conditions are introduced on a systemic basis. Otherwise, not even the best education can counteract the irresistible dynamic that the current structure of ownership and power propagates, i.e. centralization and consolidation. These dynamics do not sustain cooperation. And, we claim, they are themselves not sustainable.

\section{Coda: Educating managerial collaboration}

\section{Mindset - Open}

The university can well be characterized as an encounter that generates time or that generates an openness to future possibility, an openness to difference and to change, for the world and our engagements with and in it, ${ }^{52}$

observes philologist Thomas Docherty. Everything starts with us - academics. We strongly believe that universities are an important source of the mindset that gives birth to the social imagination. It is reflected in and by our personal beliefs and attitudes towards cooperation and competition. It is not necessary an idealistic approach but, rather, an expression of our belief in higher education as opening - or closing of

51 J.L. Austin, How to Do Things with Words, Clarendon Press, Oxford 1985.

52 Th. Docherty, Universities at War, Sage, Los Angeles 2015, p. 47. 
minds. An open mind can accept the coexistence of many, sometimes paradoxical, views of reality. As F. Scott Fitzgerald expressed it:

A test of the first-rate intelligence is the ability to hold two opposed ideas in the mind at the same time and still retain ability to function. ${ }^{53}$

This discursive approach which is the condition sine qua non for academics for any conversation which is supposed to lead to learning and opening new perspectives. Unfortunately for many, the more we stick within the social bubble created by us with support of media, the harder it is to see other view points and challenge our beliefs. In any case this is starting point of the journey for collaborative learning.

\section{Framework - Focus on team not Individual}

Our proposed framework concerns to the process of learning, starting with the recruitment, setting the stage and finally completing the formally framed educational journey. So, recruitment is directed on a creation of a diverse cohort of participants and open possibilities to build a team. This is in a stark opposition to many individually customized programmes offered by leading institutions in Europe and in the US. We believe that it creates a condition that prohibits building relations for an exchange of short-term transactions. It amplifies the atomisation present in many societies. In such circumstances even some courses and CSR projects which are supposed to teach cooperation are just another task to be completed and grade to be scored.

\section{Methods - Experience Based}

Finally, when we consider the learning process, the most important part of it is experiences-based learning. It may be applied in different forms and subjects; however, the immersion into reality and looking for common goals and actions are crucial for the learning of cooperation. It can take a number of different forms: for example, an orientation session with a focus on physical activities and cooperation, or an art project in which students will prepare, design and present on stage. It could be also a community project delivered for a charity or an informal organization. In order to make it a valuable learning experience time and team-work are required, with an addition of some reflective work. Ongoing feedback and reflection session that might include some ethnographic work, documenting the progress of the exercise, or discussions and presentations to different audiences might play an important role in the learning process.

53 F. Scott Fitzgerald quoted by H. Mintzberg, Bedtime Stories ..., op. cit., p. 96. 


\section{References}

Alvesson M., Management of Knowledge Intensive Companies, Walter de Gruyter, BerlinNew York 1995.

Austin J.L., How to Do Things with Words, Clarendon Press, Oxford 1985.

Banaszak S., Menedżerowie w społeczeństwie wspótczesnym, Wydawnictwo Naukowe UAM, Poznań 2019.

Bauman Z., Times of Interregnum, "Ethics and Global Politics" 2012, no. 5/1, pp. 49-56.

Bloom P., Rhodes C., CEO Society: The Corporate Takeover of Everyday Life, Zed Books, London 2018.

Bloomfield B.P., Best A., Management Consultants: System Development, Power and the Translation of Problems, "The Sociological Review” 1992, no. 92, pp. 533-560.

Bloomfield B.P., Danieli A., The Role of Management Consultants in the Development of Information Technology: The Indissoluble Nature of Socio-political and Technical Skills, "Journal of Management Studies" 1995, vol. 32, no. 1, January, pp. 23-47.

Bloomfield B.P., Vurdubakis Th., The Outer Limits: Monsters, Actor Networks and the Writing of Displacement, "Organization" 1999, vol. 6(4), pp. 625-647.

Centrum Edukacji Obywatelskiej, Młodzi przedsiębiorcy, 2020, https://przedsiebiorczy.ceo. org.pl/o-programie-od-a-do-z (accessed: 3.12.2020).

Cunliffe A.L., Reflexive Inquiry in Organizational Research: Questions and Possibilities, "Human Relations" 2003, no. 56/8, pp. 983-1003.

Czarniawska-Joerges B., Guillet de Monthoux P., Good Novels, Better Management: Reading Organizational Realities, Harwood, Chur 1994.

Docherty Th., Universities at War, Sage, Los Angeles 2015.

Fleming P., Resiting Work: The Corporatization of Life and Its Discontents, Temple University Press, Philadelphia 2014.

Gaertner M., Podstawy przedsiębiorczości. Program nauczania dla szkół ponadpodstawowych (liceum i technikum), OPERON, Gdynia 2019.

Gagliardi P., Czarniawska B. (eds.), Management and Humanities, Edward Elgar, London 2006.

Graeber D., Bullshit Jobs: A Theory, Allen Lane, London 2018.

Hatch M.J., Kostera M., Koźmiński A.K., Three Faces of Leadership: Manager, Artist, Priest, Blackwell, London 2005.

Huczek M., Zarządzanie jako czynnik rozwoju przedsiębiorczości, "Przedsiębiorczość - Edukacja” 2009, no. 5, pp. 88-98.

Humanistic Management Network, Our Foundations, 2018, http://humanisticmanagement. network/about-us/ (accessed: 3.12.2020).

Humanistic Management Network, The Humanistic Management Manifest, 2018, http://humanisticmanagement.network/about-us/ (accessed: 3.12.2020).

Instytut Wolności, Przedsiębiorczy w życiu $i$ w szkole, 2017, http://przedsiebiorczosc.instytut-wolnosci.pl/ (accessed: 3.12.2020).

Kant I., Groundwork of the Metaphysics of Moral, Cambridge University Press, Cambridge 1997.

Klein N., No Is Not Enough: Defeating the New Shock Politics, Penguin, London 2017.

Kociatkiewicz J., Kostera M., Zarządzanie humanistyczne. Zarys programu, "Przegląd Zarządzania” 2013, no. 4, pp. 9-19. 
Kostera M., After the Apocalypse? Finding Hope in Organizing, John Hunt Publishing / Zero Books, Washington 2020.

Kostera M., Humanistic Management [in:] B. Czarniawska (ed.), A Research Agenda for Management and Organization Studies, Edward Elgar, Cheltenham 2016, pp. 38-48.

Kostera M., Organizational Ethnography: Methods and Inspirations, Studentlitteratur, Lund 2007.

Kostera M., The Modern Crusade: The Missionaries of Management Come to Eastern Europe, "Management Learning" 1995, no. 26/3, pp. 331-352.

Latour B., Oú atterir? Comment s'orienter en politique, Éditions de la Découverte, Paris 2017.

Ludwicki T., Modele współdziałania w organizacji projektowej, Wydział Zarządzania UW, Warszawa 2002.

Mintzberg H., Bedtime Stories for Managers, Berrett-Koehler, Oakland 2019.

Mintzberg H., Rebalancing Society: Radical Renewal Beyond Left, Right, and Center, Berrett-Koehler, Oakland 2015.

Morin E., Changeons de voie. Les leçons du coronavirus, Denoël, Paris 2020.

Olimpiada Przedsiębiorczości, Biznes w uwarunkowaniach zrównoważonego rozwoju, 2020, http://www.olimpiada.edu.pl/ (accessed: 3.12.2020).

Orzechowski E., Dziś nawet żebrak musi być sprawnym menedżerem. O zarządzaniu kultura i szkolnictwem wyższym, Attyka, Kraków 2009.

Parker M., Shut Down the Business School, Pluto, London 2018.

Pirson M., Spitzeck H., Amann W., Khan Sh., von Kimakowitz E. (eds.), Humanism in Business, Cambridge University Press, Cambridge 2009.

Pirson M., Steinvorth U., Largacha-Martinez C., Dierksmeier C. (eds.), From Capitalistic to Humanistic Business, Palgrave Macmillan, London 2014.

Podstawy programowe. Szkoła podstawowa IV-VIII, 2017, https://podstawaprogramowa.pl/ Szkola-podstawowa-IV-VIII (accessed: 3.12.2020).

Podstawy przedsiębiorczości. Cele kształcenia - wymagania ogólne. Branżowa szkoła I stopnia, 2017, https://podstawaprogramowa.pl/Branzowa-szkola-I-stopnia/Podstawy-przedsiebiorczosci (accessed: 3.12.2020).

Podstawy przedsiębiorczości. Podstawy programowe. Liceum/technikum, 2017, https://podstawaprogramowa.pl/Liceum-technikum/Podstawy-przedsiebiorczosci (accessed: 3.12.2020).

Podstawy przedsiębiorczości. Podstawy programowe. Liceum/technikum, 2018, https://podstawaprogramowa.p1/Liceum-technikum/Podstawy-przedsiebiorczosci (accessed: 3.12.2020).

Porter M., The Five Competitive Forces That Shape Strategy, "Harvard Business Review" 1979/2008, January, pp. 79-93.

Rachwał T., Kilar W., Kawecki Z., Wróbel P., Edukacja w zakresie przedsiębiorczości $w$ wychowaniu przedszkolnym, szkole podstawowej i szkołach średnich $w$ świetle nowej podstawy programowej, "Przedsiębiorczość - Edukacja" 2018, no. 14, pp. 299-424, DOI: 10.24917/20833296.14.28.

Schwartz-Shea P., Yanow D., Interpretive Research Design, Routledge, London 2012.

Skidelsky E., Skidelsky R., How Much Is Enough? Money and the Good Life, Penguin, London 2012.

Standing G., Plunder of the Commons: A Manifesto for Sharing Public Wealth, Pelican, London 2019.

Streeck W., How Will Capitalism End? Essays on a Failing System, Verso, London 2017. 
Sturdy A., The Consultancy Process - An Insecure Business?, "Journal of Management Studies" 1997, vol. 34, no. 3, May, pp. 389-413.

Szkoła Podstawowa nr 369, Przedsiębiorczość, 2020, https://sp369.edupage.org/text2/ (accessed: 3.12.2020).

Tooze A., Crashed: How Decade of Financial Crises Changed the World, Allen Lane, London 2018.

Van Maanen J., Tales of the Field: On Writing Ethnography, University of Chicago Press, Chicago 1988.

Watson T.J., In Search of Management: Culture, Chaos and Control in Managerial Work, Thomson Business Press, London 1994. 